\title{
U.S. Natural Resources and Climate Change: Concepts and Approaches for Management Adaptation
}

\author{
Jordan M. West $\cdot$ Susan H. Julius $\cdot$ Peter Kareiva \\ Carolyn Enquist · Joshua J. Lawler · Brian Petersen · \\ Ayana E. Johnson - M. Rebecca Shaw
}

Received: 5 September 2008 / Accepted: 28 June 2009/Published online: 28 July 2009

(C) The Author(s) 2009. This article is published with open access at Springerlink.com

\begin{abstract}
Public lands and waters in the United States traditionally have been managed using frameworks and objectives that were established under an implicit assumption of stable climatic conditions. However, projected climatic changes render this assumption invalid. Here, we summarize general principles for management adaptations that have emerged from a major literature review. These general principles cover many topics including: (1) how to assess climate impacts to ecosystem processes that are key to management goals; (2) using management practices to support ecosystem resilience; (3) converting barriers that may inhibit management responses into opportunities for successful implementation; and (4) promoting flexible decision making that takes into account challenges of scale and thresholds. To date, the literature on management adaptations to climate change has mostly focused on strat-
\end{abstract}

The views expressed herein are those of the authors and do not represent official policies of the U.S. Environmental Protection Agency.

J. M. West $(\bowtie) \cdot$ S. H. Julius

U.S. Environmental Protection Agency, National Center

for Environmental Assessment, 1200 Pennsylvania

Avenue NW (8601P), Washington, DC 20460, USA

e-mail: west.jordan@epa.gov

P. Kareiva

The Nature Conservancy, 4722 Latona Avenue NE, Seattle, WA 98105, USA

C. Enquist

The Nature Conservancy in New Mexico, Santa Fe, NM 87501, USA

J. J. Lawler

College of Forest Resources, University of Washington,

Box 352100, Seattle, WA 98195-2100, USA egies for bolstering the resilience of ecosystems to persist in their current states. Yet in the longer term, it is anticipated that climate change will push certain ecosystems and species beyond their capacity to recover. When managing to support resilience becomes infeasible, adaptation may require more than simply changing management practices-it may require changing management goals and managing transitions to new ecosystem states. After transitions have occurred, management will again support resilience-this time for a new ecosystem state. Thus, successful management of natural resources in the context of climate change will require recognition on the part of managers and decisions makers of the need to cycle between "managing for resilience" and "managing for change."

Keywords Climate change - Adaptation ·

Resource management · Ecosystems · Resilience · Uncertainty · Triage · Thresholds

B. Petersen

Environmental Studies Department, University of California, Santa Cruz, 1156 High Street, Santa Cruz, CA 95064, USA

A. E. Johnson

Center for Marine Biodiversity and Conservation,

Scripps Institution of Oceanography, University of California,

San Diego, 9500 Gilman Drive \#0208, La Jolla,

CA 92093-0208, USA

M. R. Shaw

The Nature Conservancy, 201 Mission Street, 4th Floor,

San Francisco, CA 94105, USA 


\section{Introduction}

Natural resource management practices in the United States were developed under relatively stable climatic conditions in the last century, and based on the presumption that ecological systems tend toward a natural equilibrium state for which one could manage (Dixon 2003; US-GAO 2007; Heller and Zavaleta 2009). However, it is now understood that widespread ecological sensitivities to climate variability and change necessitate a re-examination of management practices in the context of a dynamic climate system (Adger and others 2007). A recent report commissioned by the United States Climate Change Science Program (CCSP 2008) reviewed management practices for reducing the impact of climate change on sensitive ecosystems and natural resources. The report, which examined selected management systems for protected lands and waters within the United States (i.e., National Forests, National Parks, National Wildlife Refuges, Wild and Scenic Rivers, National Estuaries, and Marine Protected Areas), was written by a team of 61 scientists and managers and represents the largest review to date of management adaptations. This article examines concepts and approaches distilled from across the management systems reviewed in the report and concludes that only through a transformation of management and goal-setting approaches-from a static equilibrium view of the natural world to a highly dynamic and variable approach-will it be possible to make major advances in adaptation to climate change.

Adaptation to climate change refers to adjustments in natural or human systems in response to climate change or impacts (IPCC 2001). In biological disciplines, adaptation refers to the process of genetic change within a population due to natural selection, whereby the average state of a character becomes better suited to some feature of the environment (Groom and others 2006). This type of adaptation, also referred to as autonomous adaptation (IPCC 2001), is a reactive biological response to climate stimuli and does not involve intervention by society. Planned adaptation (i.e., management adaptation), on the other hand, refers to strategies adopted by society to manage systems based on an awareness that conditions are about to change or have changed, such that action is required to meet management goals (modified from IPCC 2001). This article focuses on this latter form of adaptation.

Thus far, the literature has focused largely on management adaptations that increase the resilience of ecological systems to climate change (Scheffer and others 2001; Turner II and others 2003; Tompkins and Adger 2004; Hansen and others 2003; Grimsditch and Salm 2006; Walker and Salt 2006; Heller and Zavelata 2009). Here, resilience refers to the amount of change or disturbance that a system can absorb before it undergoes a fundamental shift to a different set of processes and structures (Holling 1973; Gunderson 2000; Bennett and others 2005). Thus, the adaptation approaches discussed in the first part of this review consist of strategies for supporting the ability of ecosystems to persist at local or regional scales. Only more recently has the science and management community begun to grapple with what constitutes adaptation when resilience can no longer be maintained (Millar and others 2007); a discussion of this emergent topic takes place in a later section.

This article begins with an overview of the prerequisite for any adaptation effort: an assessment of likely current and future climate change impacts on ecosystem processes associated with management goals. This is followed by a review of management adaptation strategies currently available from the literature (resilience approaches). A subsequent section discusses real or perceived barriers to implementation in terms of how they may be converted into opportunities for success. Final sections discuss management under conditions in which thresholds are exceeded and goals become unattainable, as well as observations about the steps necessary to advance the management community's capability to adapt.

\section{Assessing Impacts to Support Adaptation}

Specific management goals for ecosystems in different management systems (e.g., National Refuges or National Estuaries) vary based on the principles and frameworks adopted by their associated management communities. Goals are commonly expressed in terms of maintaining ecosystem integrity, achieving restoration, preserving ecosystem services, and protecting wildlife and other ecosystem characteristics (CCSP 2008). The achievement of management goals is thus dependant on the ability to protect, support, and restore the structure and functioning of ecosystems.

Changes in climate may affect ecosystems such that management goals are not achieved. Identified management goals should be analyzed for their sensitivity to climate variability and change, as well as to other stressors present in the system that may interact with climate change (Kareiva and others 2008). Adaptations to climate variability and change are meant to reduce the risk of failing to achieve management goals.

The first step is to understand how climate change will impact key ecosystem components and processes that are essential to attaining management goals. Impact assessments combine our understanding of the current state of the system with drivers of environmental change to project potential responses to changes in those drivers (Carter and others 1994; Carter and others 2007). Climate change impacts are defined by (1) the character and magnitude of 
climate changes likely to affect a given location, and (2) the sensitivity of a given conservation target to climate change. Assessing the nature of the changes a population or system is likely to experience requires projections of changes in both climate and climate-driven processes (Baron and others 2008; Scott and others 2008). For example, managing forests in a changing climate requires data on projected changes in rainfall and temperature-as well as data on current and projected condition of vegetation-in order to understand processes such as changing fire regimes (Joyce and others 2008).

Sensitivities of target organisms or processes to climate change depend on several aspects of the biology of a species or the ecological functioning of a system. A screening of sensitivities can be performed through a literature review of critical thresholds (Carpenter and others 1999; Scheffer and Carpenter 2003; Burkett and others 2005; Groffman and others 2006) and coping ranges (Yohe and Tol 2002; Willows and Connell 2003; Burton and others 2005; Carter and others 2007), which provides the basis for understanding the implications of changes in future conditions. For example, species that are physiologically sensitive to changes in temperature or moisture; species that occupy climate-sensitive habitats such as shallow wetlands, perennial streams, and alpine areas; and species with limited dispersal abilities will be sensitive to climate change (Root and Schneider 2002). Populations with slow growth rates and populations at species range boundaries are also likely to be sensitive (Pianka 1970; Lovejoy and Hannah 2005), as will species, communities, or ecosystems that are highly dependant on specific climate-driven processes such as fire regimes, sea level rise, and hydrology.

\section{Establishing Baseline Information}

In addition to understanding which organisms and systems are most sensitive to climate change, managers need to know the baseline conditions of a given system. Ecologists, especially marine ecologists, have drawn attention to the fact that the world has changed so much that it can be hard to determine an accurate historical baseline for any system (Pauly 1995; Jackson and others 2001). An understanding of a system's long history can be essential because the historical record may include information about past responses to extreme stresses and perturbations. When dealing with sensitive, endangered, or stressed systems, experimental perturbation is not feasible. When available, paleoecological records can be used to examine past ranges of natural environmental variability and past organismal responses to climate change (Willis and Birks 2006). Although in an experimental sense "uncontrolled," there is no lack of both historic and recent examples of perturbations and recoveries through which to examine resilience.
Historic baselines have the potential to offer insights into how to manage for climate change. For example, while the authority to acquire land interests and water rights exists under the Wild and Scenic Rivers Act, lack of baseline data on flow regimes makes it difficult to determine how, when, and where to use this authority (Palmer and others 2008). Data on species composition and distribution; rates of freshwater discharge into estuaries; river flooding regimes; magnitude and timing of anadromous fish runs; forest fire regimes; and home ranges, migration patterns, and reproductive dynamics of sensitive organisms would all be useful for making management decisions given the potential effects of climate change (Joyce and others 2008; Scott and others 2008; Peterson and others 2008; Palmer and others 2008).

However, baselines also have the potential to be misleading. For example, Joyce and others (2008) noted that historic baselines are useful only if climate is incorporated into those past baselines and the relationship of vegetation to climate is explored. An ecological baseline based on an historic climate that will never again be seen in a region should not be used as a goal. At the same time, adjusting baselines to accommodate changing conditions requires caution to avoid unnecessarily compromising ecosystem integrity for the future and losing valuable historical knowledge.

\section{Monitoring to Inform Management Decisions}

Although monitoring is already recognized as an important component of management, in the face of climate change, monitoring will be even more essential. Monitoring will be needed to detect changes in baseline conditions as well as to facilitate timely adaptation actions. Monitoring also provides a means to gauge the effectiveness of management actions. Some monitoring may be designed to detect general ecological trends in poorly understood systems. However, most monitoring programs should be designed with specific hypotheses in mind and with trigger points that will initiate a policy or management re-evaluation (Gregory and others 2006). For instance, using a combination of baseline and historical data, a monitoring program could be set up with pre-defined thresholds for a species' abundance or growth rate, or a river's flow rate, which, once exceeded, would prompt a re-examination of management objectives.

Monitoring targets will have to be carefully selected to represent the system in a tractable way and to give clear information about possible management options (Gregory and Failing 2002). Some systems will require site-specific monitoring, whereas others will be able to take advantage of more general monitoring programs (see Kareiva and others 2008 for examples of potential monitoring targets). For instance, Joyce and others (2008) highlight the need to 
monitor both native plant species and non-native species while suggesting a more general monitoring program would be adequate to detect changes in tree establishment, growth and mortality. One example of such a general program is the National Phenology Network's monitoring of the timing of ecological events across the country (Joyce and others 2008).

Although directed, intensive monitoring programs may seem daunting, there are several opportunities to build on existing and developing efforts. Opportunities include the National Science Foundation's National Ecological Observation Network and the Park Service's Vital Signs program (e.g., Mau-Crimmins and others 2005). Some federal lands have detailed species inventories (e.g., the national parks are developing extensive species inventories for the Natural Resource Challenge; Baron and others 2008) or detailed stream flow measurements. However, while monitoring is critical, it is only one step in the management process and does not itself address the effects of climate change.

\section{Incorporating Uncertainty into Impact Assessments}

Even when equipped with climate projections, baseline information and monitoring data, managers still face very complex decisions. The high degree of uncertainty inherent in assessments of climate change impacts can make it difficult for a manager to translate results from those assessments into practical management actions (Dessai and others 2009). However, uncertainty is not the same as ignorance or lack of information - it simply means that there is more than one outcome possible as a result of climate change. Fortunately, there are approaches for dealing with uncertainty that allow progress. One key step is scenario-building (Hannah and others 2002; Johnson and Weaver 2009).

While it is not possible to predict the changes that will occur, managers can get an indication of the expected range of changes using scenarios, and they can use that range to develop appropriate responses. Rather than focusing on a single "most likely" outcome, planning for the range will provide responses that are more robust to climate change (Johnson and Weaver 2009). To develop a set of scenarios-i.e., internally consistent views of reasonably plausible futures in which decisions may be explored (adapted from Porter 1985; IPCC 1994; Schwartz 1996) - quantitative or qualitative visions of the future are developed. These scenarios explore current assumptions and expand viewpoints of the future. In the climate change impacts area, approaches for developing scenarios may range from model-based scenarios, to analog scenarios, to informal synthetic scenarios.

Model-based scenarios explore plausible future conditions through direct representations of complex patterns of change. Scenarios are developed using a number of different realizations from global climate models that are driven by multiple alternative future emissions paths. The outputs are spatially downscaled using statistical methods or regional climate models, and the resulting scenarios become the basis for exploring potential ecosystem responses. Analog scenarios make use of existing climate information, either at the region in question (temporal analogs) or from another region that currently experiences a climate anticipated to resemble the future climate of the site under study (spatial analogs). Temporal analogs may be constructed from paleoclimate information or from the historical instrumental record. Synthetic scenarios specify changes in particular variables and apply those changes to an observed time series. For example, a historic time series of annual mean precipitation for the northeastern United States would be increased by $2 \%$ to create a synthetic scenario, but no other characteristics of precipitation would change. A synthetic scenario might start by simply stating that in the future, summers will be hotter and drier. That scenario would be used to alter the sets of historic time series, and decision makers would explore how management might respond (IPCC-TGICA 2007).

Along with developing multiple scenarios using the methods described above to discover potential ecosystem changes, it may also be useful to conduct sensitivity analyses that further explore ecosystem behaviors and identify ranges of potential changes in ecosystem endpoints. In such analyses, key attributes of an ecosystem are examined to see how they respond to systematic changes in selected climate drivers (IPCC-TGICA 2007; Johnson and Weaver 2009). For example, precipitation and temperature would be perturbed at specific increments over a plausible range of changes-e.g., $1 \%$ changes in precipitation over a range of $-5 \%$ to $+10 \%$ from the historic baseline, and $1{ }^{\circ} \mathrm{C}$ changes in temperature over a range of $+1^{\circ}$ to $+4^{\circ} \mathrm{C}$ from the historic baseline-as inputs to an ecosystem model to determine how ecosystem processes and endpoints would respond. This approach may help managers to identify thresholds beyond which key management goals become unattainable.

Scenario-building approaches and sensitivity analyses provide the foundation for scenario planning-planning for multiple possible future events (Peterson and others 2003; Carpenter and others 2006; Cumming 2007). If sensitivity analyses are performed, those results can be used to select the most relevant scenarios that both address managers' needs and represent the widest possible, but still plausible, futures. The strategy is to then design a variety of management strategies that are robust across the whole range of scenarios and associated impacts. For detailed guidance on using scenario data for climate impact assessments, see IPCC-TGICA (2007). 


\section{Management Strategies for Resilience to Climate Change}

Management of ecosystems for any objective will be made easier if the systems are resilient to change-whether it is climate change or any other disturbance. For example, a highly resilient coral reef might bleach but would be able to recover rapidly (Keller and others 2008). Similarly, a resilient forest ecosystem would quickly re-establish plant cover following a major forest fire, with negligible loss of soils or fertility (Joyce and others 2008). An important contributing factor to overall resilience is resistance, which is the ability of an organism or a system to remain structurally and functionally un-impacted by major disturbance or stress (Grime and others 2000; Grimsditch and Salm 2006). "Un-impacted," in this sense, means that the species or system can continue to provide the desired ecosystem services. Resistance contributes to resilience since ecosystems that contain resistant individuals or communities will exhibit faster overall recovery (through recruitment and regrowth) after a disturbance.

\section{Adaptation Approaches}

Ecological studies combined with managers' expertise reveal several categories of approaches for managing natural systems for resilience in the face of disturbance. Insights from experiences with unpredictable and extreme events such as hurricanes, floods, pest and disease outbreaks, invasions, and forest fires can be readily applied to managing in the context of climate change. A clear exposition of these approaches is the starting point for developing best practices aimed at climate adaptation. The seven approaches discussed below-(1) reduce anthropogenic stresses, (2) protect key ecosystem features, (3) maintain representation, (4) replicate, (5) restore, (6) identify refugia, and (7) relocate organisms-involve techniques that enhance a system's resilience to climatic changes. All of these adaptation approaches ultimately contribute to resilience, whether at the scale of individual protected area units, or at the scale of regional/national systems. The seven categories are inclusive of the range of adaptation options found across the six management systems reviewed in the CCSP (2008) report. It is important to note that the strategies discussed under these approaches are options, not recommendations; the efficacy of many of the individual strategies has yet to be fully tested and would depend on the specifics of place, ecosystem, project design, etc.

\section{Reduce Anthropogenic Stresses}

Managing for resilience often implies minimizing anthropogenic stressors (e.g., pollution, overfishing) that hinder the ability of species or ecosystems to withstand a stressful climatic event. For example, one way of enhancing resilience in wildlife refuges is to reduce other stresses on native vegetation such as erosion or altered hydrology caused by human activities (Scott and others 2008). Marine protected area managers may focus on human stressors such as overfishing and excessive inputs of nutrients, sediments, and pollutants, both inside the protected area and on adjacent land and waters (Keller and others 2008). The resilience of rivers could be enhanced by strategically shifting access points or moving existing trails for wildlife or river enthusiasts in order to protect important riparian zones (Palmer and others 2008). See Table 1 for additional examples drawn from across the management systems reviewed in CCSP (2008).

\section{Protect Key Ecosystem Features}

Within ecosystems, there may be particular structural characteristics (e.g., three-dimensional complexity, growth patterns), organisms (e.g., functional groups, native species), or areas (e.g., buffer zones, migration corridors) that are particularly important for promoting the resilience of the overall system. Such key ecosystem features could be important focal points for special management protections or actions. For example, managers of national forests may proactively promote stand resilience to diseases and fires by using silviculture techniques such as widely spaced thinnings or shelterwood cuttings (Joyce and others 2008). Another example would be to aggressively prevent or reverse the establishment of invasive non-native species that threaten native species or impede current ecosystem function (Baron and others 2008). Preserving the structural complexity of vegetation in tidal marshes, seagrass meadows, and mangroves may render estuaries more resilient (Peterson and others 2008). Establishing and protecting corridors of connectivity that enable migrations can enhance resilience across landscapes in national wildlife refuges (Scott and others 2008). See Table 2 for additional examples drawn from across the management systems reviewed in CCSP (2008).

\section{Maintain Representation}

Representation involves the protection of the greatest diversity of biotic and abiotic systems possible. Depending on the application, this could mean protecting multiple genetically-variable populations of a species, protecting different communities of an ecosystem type, or protecting a variety of habitats. A management plan for a large ecosystem that includes representation of all possible combinations of physical environments and biological communities increases the chances that, regardless of the climatic change 
Table 1 Examples of potential adaptation actions that focus on reduction of anthropogenic stresses as a means of supporting resilience; many of these options are not yet proven and require testing

Adaptation approach: reduce anthropogenic stresses

National Forests (Joyce and others 2008)

$\checkmark$ Reduce the impact of current anthropogenic stressors such as fragmentation (e.g., by creating larger management units and migration corridors) and uncharacteristically severe wildfires and insect outbreaks (e.g., by reducing stand densities and abating fuels)

$\checkmark$ Identify and take early proactive action against non-native invasive species (e.g., by using early detection and rapid response approaches) National Parks (Baron and others 2008)

$\checkmark$ Remove structures that harden the coastlines, impede natural regeneration of sediments, and prevent natural inland migration of sand and vegetation after disturbances

$\checkmark$ Reduce or eliminate water pollution by working with watershed coalitions to reduce non-point sources and with local, state and federal agencies to reduce atmospheric deposition

$\checkmark$ Manage Park Service and visitor use practices to prevent people from inadvertently contributing to climate change

National Wildlife Refuges (Scott and others 2008)

$\checkmark$ Reduce human water withdrawals to restore natural hydrologic regimes

Wild \& Scenic Rivers (Palmer and others 2008)

$\checkmark$ Purchase or lease water rights to enhance flow management options

$\checkmark$ Manage water storage and withdrawals to smooth the supply of available water throughout the year

$\checkmark$ Develop more effective stormwater infrastructure to reduce future occurrences of severe erosion

$\checkmark$ Consider shifting access points or moving existing trails for wildlife or river enthusiasts

National Estuaries (Peterson and others 2008)

$\checkmark$ Conduct integrated management of nutrient sources and wetland treatment of nutrients to limit hypoxia and eutrophication

$\checkmark$ Manage water resources to ensure sustainable use in the face of changing recharge rates and saltwater infiltration

$\checkmark$ Prohibit bulkheads and other engineered structures on estuarine shores to preserve or delay the loss of important shallow-water habitats by permitting their inland migration as sea levels rise

Marine Protected Areas (Keller and others 2008)

$\checkmark$ Manage human stressors such as overfishing and excessive inputs of nutrients, sediments, and pollutants within marine protected areas

$\checkmark$ Improve water quality by raising awareness of adverse effects of land-based activities on marine environments, implementing integrated coastal and watershed management, and developing options for advanced wastewater treatment

that occurs, somewhere in the system there will be areas that provide a source for recovery. Employing this approach with wildlife refuges may be particularly important for migrating birds because they use a diverse array of habitats at different stages of their life cycles and along their migration routes, all of which will be affected by climate change (Scott and others 2008). At the level of species, it may be possible to increase genetic diversity in river systems through plantings or via stocking fish (Palmer and others 2008), or maintain complexity of salt marsh landscapes by preserving marsh edge environments (Peterson and others 2008). See Table 3 for additional examples drawn from across the management systems reviewed in CCSP (2008).

\section{Replicate}

Replication is simply managing for the continued survival of more than one example of each ecosystem or species, even if the replicated examples are similar. Increasing redundancy acts as a form of insurance against the unpredictable nature of climate change. With marine protected areas, replication is explicitly used as a way to spread risk: if one area is negatively affected by a disturbance, then species, genotypes, and habitats in another area provide both insurance against extinction and a larval supply for recovery of affected areas (Keller and others 2008). The analogy for forests would be spreading risks by increasing ecosystem redundancy and buffers in both natural environments and plantations (Joyce and others 2008). It is prudent to use replication in all systems. In practice, most replication strategies also serve as representation strategies (since no two populations or ecosystems can ever be truly identical), and conversely most representation strategies provide some form of replication. See Table 4 for additional examples drawn from across the management systems reviewed in CCSP (2008).

\section{Restore}

In many cases functionally intact ecosystems confer more resilience to extreme events such as floods and storms. Thus restoration of degraded ecosystems can be a valid 
Table 2 Examples of adaptation actions that focus on protection of key ecosystem features as a means of supporting resilience; many of these options are not yet proven and require testing

Adaptation approach: protect key ecosystem features

National Forests (Joyce and others 2008)

$\checkmark$ Facilitate natural (evolutionary) adaptation through management practices (e.g., prescribed fire and other silvicultural treatments) that shorten regeneration times and promote interspecific competition

$\boldsymbol{V}$ Promote connected landscapes to facilitate species movements and gene flow, sustain key ecosystem processes (e.g., pollination and dispersal), and protect critical habitats for threatened and endangered species

National Parks (Baron and others 2008)

$\checkmark$ Remove barriers to upstream migration in rivers and streams

$\checkmark$ Reduce fragmentation and maintain or restore species migration corridors to facilitate natural flow of genes, species and populations

$\checkmark$ Use wildland fire, mechanical thinning, or prescribed burns where it is documented to reduce risk of anomalously severe fires

$\checkmark$ Minimize alteration of natural disturbance regimes, for example through protection of natural flow regimes in rivers or removal of infrastructure that prohibits the allowance of wildland fire

$\checkmark$ Aggressively prevent establishment of invasive non-native species or diseases where they are documented to threaten native species or current ecosystem function

National Wildlife Refuges (Scott and others 2008)

$\checkmark$ Manage risk of catastrophic fires through prescribed burns

$\checkmark$ Reduce or eliminate stressors on conservation target species

$\boldsymbol{V}$ Improve the matrix surrounding the refuge by partnering with adjacent owners to improve/build new habitats

$\boldsymbol{V}$ Install levees and other engineering works to alter water flows to benefit refuge species

$\boldsymbol{V}$ Remove dispersal barriers and establish dispersal bridges for species

$\checkmark$ Use conservation easements around the refuge to allow species dispersal and maintain ecosystem function

$\checkmark$ Facilitate migration through the establishment and maintenance of wildlife corridors

Wild \& Scenic Rivers (Palmer and others 2008)

$\checkmark$ Maintain the natural flow regime through managing dam flow releases upstream of the wild and scenic river (through option agreements with willing partners) to protect flora and fauna in drier downstream river reaches, or to prevent losses from extreme flooding

$\checkmark$ Use drought-tolerant plant varieties to help protect riparian buffers

$\checkmark$ Create wetlands or off-channel storage basins to reduce erosion during high flow periods

$\checkmark$ Actively remove invasive species that threaten key native species

National Estuaries (Peterson and others 2008)

$\boldsymbol{V}$ Help protect tidal marshes from erosion with oyster breakwaters and rock sills and thus preserve their water filtration and fisheries enhancement functions

$\checkmark$ Preserve and restore the structural complexity and biodiversity of vegetation in tidal marshes, seagrass meadows, and mangroves

$\checkmark$ Adapt protections of important biogeochemical zones and critical habitats as the locations of these areas change with climate

$\checkmark$ Connect landscapes with corridors to enable migrations to sustain wildlife biodiversity across the landscape

$\checkmark$ Develop practical approaches to apply the principle of rolling easements to prevent engineered barriers from blocking landward retreat of coastal marshes and other shoreline habitats as sea level rises

Marine Protected Areas (Keller and others 2008)

$\checkmark$ Identify ecological connections among ecosystems and use them to inform the design of MPAs and management decisions such as protecting resistant areas to ensure sources of recruitment for recovery of populations in damaged areas

$\checkmark$ Manage functional species groups necessary to maintaining the health of reefs and other ecosystems

$\checkmark$ Design marine protected areas with dynamic boundaries and buffers to protect breeding and foraging habits of highly migratory and pelagic species

$\checkmark$ Monitor ecosystems and have rapid-response strategies prepared to assess ecological effects of extreme events as they occur

$\checkmark$ Identify and protect ecologically significant ("critical”) areas such as nursery grounds, spawning grounds, and areas of high species diversity

management adaptation to climate change. For example, the restoration of wetlands and natural floodplains can increase resilience to floods. Restoration of particular species assemblages may also be critical to managing for resilience-a good example of this would be fire-adapted vegetation in forests that are expected to see more fires as a result of hotter and drier summers (Joyce and others 2008). At Blackwater National Wildlife Refuge, the United States Fish and Wildlife Service is planning to restore wetlands that may otherwise be inundated by 2100 (Scott and others 
Table 3 Examples of adaptation actions that focus on representation as a means of supporting resilience; many of these options are not yet proven and require testing

Adaptation approach: represent

National Forests (Joyce and others 2008)

$\checkmark$ Modify genetic diversity guidelines to increase the range of species, maintain high effective population sizes, and favor genotypes known for broad tolerance ranges

$\boldsymbol{V}$ Where ecosystems will very likely become more water limited, manage for drought- and heat-tolerant species and populations, and where climate trends are less certain, manage for a variety of species and genotypes with a range of tolerances to low soil moisture and higher temperatures

National Parks (Baron and others 2008)

$\checkmark$ Allow the establishment of species that are non-native locally, but which maintain native biodiversity or enhance ecosystem function in the overall region

$\checkmark$ Actively plant or introduce desired species after disturbances or in anticipation of the loss of some species

National Wildlife Refuges (Scott and others 2008)

$\checkmark$ Strategically expand the boundaries of refuges to increase ecological, genetic, geographical, behavioral and morphological variation in species

$\checkmark$ Facilitate the growth of plant species more adapted to future climate conditions

Wild \& Scenic Rivers (Palmer and others 2008)

$\checkmark$ Increase genetic diversity through plantings or by stocking fish

$\boldsymbol{V}$ Increase physical habitat heterogeneity in channels to support diverse biotic assemblages

National Estuaries (Peterson and others 2008)

$\checkmark$ Maintain high genetic diversity through strategies such as the establishment of reserves specifically for this purpose

$\boldsymbol{V}$ Maintain landscape complexity of salt marsh landscapes, especially preserving marsh edge environments

Marine Protected Areas (Keller and others 2008)

$\checkmark$ Maximize habitat heterogeneity within marine protected areas and consider protecting larger areas to preserve biodiversity, biological connections among habitats, and ecological functions

$\checkmark$ Include entire ecological units (e.g., coral reefs with their associated mangroves and seagrasses) in marine protected area design to maintain ecosystem function and resilience

$\checkmark$ Ensure that the full breadth of habitat types is protected (e.g., fringing reef, fore reef, back reef, patch reef)

Table 4 Examples of adaptation actions that focus on replication as a means of supporting resilience; many of these options are not yet proven and require testing

Adaptation approach: replicate

National Forests (Joyce and others 2008)

$\checkmark$ Spread risks by increasing ecosystem redundancy and buffers in both natural environments and plantations

National Parks (Baron and others 2008)

$\boldsymbol{V}$ Practice bet-hedging by replicating populations and gene pools of desired species

National Wildlife Refuges (Scott and others 2008)

$\checkmark$ Provide redundant refuge types to reduce risk to trust species

Wild \& Scenic Rivers (Palmer and others 2008)

$\checkmark$ Establish special protection for multiple headwater reaches that support keystone processes or sensitive species

National Estuaries (Peterson and others 2008)

$\checkmark$ When restoring oyster reefs, replicate reefs along a depth gradient to allow fish and crustaceans to survive when depth-dependant environmental degradation occurs

$\checkmark$ Support migrating shorebirds by ensuring protection of replicated estuaries along the flyway

Marine Protected Areas (Keller and others 2008)

$\checkmark$ Replicate habitat types in multiple areas to spread risks associated with climate change

2008). In the case of estuaries, restoring the vegetational layering and structure of tidal marshes, seagrass meadows, and mangroves can stabilize estuary function (Peterson and others 2008). See Table 5 for additional examples drawn from across the management systems reviewed in CCSP (2008). 
Table 5 Examples of adaptation actions that focus on restoration as a means of supporting resilience; many of these options are not yet proven and require testing

Adaptation approach: restore

National Forests (Joyce and others 2008)

$\checkmark$ Use the paleological record and historical ecological studies to revise and update restoration goals so that selected species will be tolerant of anticipated climate

$\checkmark$ Where appropriate after large-scale disturbances, reset succession and manage for asynchrony at the landscape scale by promoting diverse age classes and species mixes, a variety of successional stages, and spatially complex and heterogeneous vegetation structure

National Parks (Baron and others 2008)

$\checkmark$ Restore vegetation where it confers biophysical protection to increase resilience, including riparian areas that shade streams and coastal wetland vegetation that buffers shorelines

$\checkmark$ Minimize soil loss after fire or vegetation dieback using native vegetation and debris

National Wildlife Refuges (Scott and others 2008)

$\checkmark$ Restore and increase habitat availability and reduce stressors in order to capture the full geographical, geophysical, and ecological ranges of species on as many refuges as possible

Wild \& Scenic Rivers (Palmer and others 2008)

$\checkmark$ Conduct river restoration projects to stabilize eroding banks, repair in-stream habitat, or promote fish passages from areas with high temperatures and less precipitation

$\checkmark$ Restore the natural capacity of rivers to buffer climate-change impacts (e.g., through land acquisition around rivers, levee setbacks to free the floodplain of infrastructure, riparian buffer repairs)

National Estuaries (Peterson and others 2008)

$\checkmark$ Restore important native species and remove invasive non-natives to improve marsh characteristics that promote propagation and production of fish and wildlife

$\checkmark$ Direct estuarine habitat restoration projects to places where the restored ecosystem has room to retreat as sea level rises

Marine Protected Areas (Keller and others 2008)

$\checkmark$ Following extreme events, consider whether actions should be taken to enhance natural recovery processes through active restoration

$\checkmark$ Consider mangrove restoration for potential benefits including shoreline protection, expansion of nursery habitat, and release of tannins and other dissolved organic compounds that may reduce photo-oxidative stress in corals

\section{Identify Refugia and Relocate Organisms}

The term refugia refers to physical environments that are less affected by climate change than other areas (e.g., due to local currents, geographic location, etc.) and are thus a "refuge" from climate change for organisms. Relocation refers to human-facilitated transplantation of organisms from one location to another in order to bypass a barrier (e.g., an urban area). This approach is also referred to as assisted colonization or assisted migration (see HoeghGuldberg and others 2008, for example). Refugia and relocation, while distinct concepts, are actually subsets of one or more of the approaches listed above. For example, if refugia can be identified locally, they can be considered sites for long-term retention of species (e.g., for representation and to maintain resilience) in forests (Joyce and others 2008). Or, in national wildlife refuges, it may be possible to use restoration techniques to reforest riparian boundaries with native species to create shaded thermal refugia for fish species (Scott and others 2008). In the case of relocation, an example would be transport of fish populations in the Southwest that become stranded as water levels drop to river reaches with appropriate flows (e.g., to preserve species representation and system-wide resilience; Palmer and others 2008). Transplantation of organisms among national parks could preserve system-wide representation of species that would not otherwise be able to overcome barriers to dispersal (Baron and others 2008). See Tables 6 and 7 for additional examples drawn from across the management systems reviewed in CCSP (2008).

\section{Adaptive Management}

Once adaptation strategies have been selected, adaptive management is likely to be an effective method for implementation, given uncertainty in their effectiveness. Adaptive management is an iterative process in which management actions are followed by targeted monitoring, the results of which inform changes in management actions (Walters and Hilborn 1978). In this cyclic process, management actions serve as full-scale field experiments. Since adaptive management emphasizes managing based on observation and continuous learning, it provides a means for addressing varying degrees of uncertainty in our knowledge of current and future climate change impacts (Holling 1978; Walters 1986; FEMAT 1993; Moir and 
Table 6 Examples of adaptation actions that focus on the use of refugia as a means of supporting resilience; many of these options are not yet proven and require testing

Adaptation approach: identify refugia

National Forests (Joyce and others 2008)

$\checkmark$ Use the paleological record and historical ecological studies to identify environments buffered against climate change, which would be good candidates for long-term conservation

National Parks (Baron and others 2008)

$\checkmark$ Create or protect refugia for valued aquatic species at risk to the effects of early snowmelt on river flow

National Wildlife Refuges (Scott and others 2008)

$\checkmark$ Reforest riparian boundaries with native species to create shaded thermal refugia for fish species in rivers and streams

$\checkmark$ Identify climate change refugia and acquire necessary land

Wild \& Scenic Rivers (Palmer and others 2008)

$\checkmark$ Plant riparian vegetation to provide fish and other organisms with refugia

$\checkmark$ Acquire additional river reaches for the wild and scenic river where they contain naturally occurring refugia from climate change stressors

$\checkmark$ Create side-channels and adjacent wetlands to provide refugia for species during droughts and floods

National Estuaries (Peterson and others 2008)

$\checkmark$ Restore oyster reefs along a depth gradient to provide shallow water refugia for mobile species such as fish and crustaceans to retreat to in response to climate-induced deep water hypoxia/anoxia

Marine Protected Areas (Keller and others 2008)

$\checkmark$ Identify and protect areas observed to be resistant to climate change effects or to recover quickly from climate-induced disturbances

$\checkmark$ Establish dynamic marine protected areas defined by large-scale oceanographic features such as oceanic fronts where changes in types and abundances of organisms often occur

Table 7 Examples of adaptation actions that focus on relocation as a means of supporting resilience; many of these options are not yet proven and require testing

Adaptation approach: relocate

National Forests (Joyce and others 2008)

$\checkmark$ Establish or strengthen long-term seed banks to create the option of re-establishing extirpated populations in new/more appropriate locations National Parks (Baron and others 2008)

$\checkmark$ Assist in species migrations

National Wildlife Refuges (Scott and others 2008)

$\checkmark$ Facilitate long-distance transport of threatened endemic species

$\checkmark$ Facilitate interim propagation and sheltering or feeding of mistimed migrants, holding them until suitable habitat becomes available

Wild \& Scenic Rivers (Palmer and others 2008)

$\checkmark$ Establish programs to move isolated populations of species of interest that become stranded when water levels drop

Block 2001; Stankey and others 2003). Adaptive management in the context of climate change involves the consideration of potential climate impacts, the design of management actions that take those impacts into account, monitoring of climate-sensitive species and processes to measure management effectiveness, and the redesign and implementation of improved (or new) management actions. Examples include flood release experiments in the Grand Canyon (Baron and others 2008) and at the Glen Canyon dam (National Research Council 1999). Releasing water from a dam allows for the application of highly regulated experimental treatments and assessments of effects.

Recent examinations of the difficulty of implementing adaptive management have emphasized that the temporal and spatial scale, dimensions of uncertainty, risks, and insufficient institutional support can create major difficulties with applying adaptive management. When one considers adaptive management in response to climate change, every one of these potential difficulties is at play (Arvai and others 2006; Gregory and others 2006). The critical challenge will be to state explicit scientific hypotheses; establish monitoring programs with predefined triggers that initiate a re-examination of management approaches; and create flexible policies and institutional frameworks (Gregory and others 2006). These challenges do not mean adaptive management is impossible —only that attention to hypotheses, monitoring, periodic re-evaluations, and flexibility are necessary. 


\section{Barriers and Opportunities for Implementation}

Although there may be many theoretically possible adaptation strategies, a very real consideration for managers is whether they are feasible. Factors that can limit or enhance managers' ability to implement options may be technical, economic, social, or political. Understanding these barriers helps in assessing the feasibility of specific adaptation options and identifying corresponding opportunities for improving implementation success.

Barriers and opportunities can be divided into four categories: (1) legislation and regulations, (2) management policies and procedures, (3) human and financial capital, and (4) information and science. As pertains to protected areas in the United States, these barriers and opportunities stem from mission statements and management principles. The federal land and water management systems reviewed in CCSP (2008) are mandated by law to preserve and protect the nation's natural resources. However, the specific management goals vary across systems due to the unique mission statements articulated in their founding legislations. Missions are then manifested through management principles that interpret those goals in ways that may inhibit or enhance the capability to adapt.

\section{Legislation and Regulations}

Federal land and water managers can use existing legislative tools opportunistically by applying traditional features or levers in non-traditional ways (see Table 8). For example, legislative features can be used to coordinate management outside of jurisdictional boundaries. Generally, the United States Fish and Wildlife Service has ample proprietary authority to engage in transplantation/relocation, habitat engineering (including irrigation-hydrologic management), and captive breeding to support conservation (Scott and others 2008). These activities are especially applicable to managing shifts in species distributions and preventing species extirpations likely to result from climate change. Portions of existing legislation could also be used to influence dam operations at the state level as a means of providing adaptive flow controls under future climate changes (e.g., using the Clean Water Act to prevent low flows in vulnerable stream reaches, adjusting thermal properties of flows). As these examples suggest, climate change impacts often can be addressed within existing legislative frameworks.

\section{Management Policies and Procedures}

Each management system mandates the development of a management plan. Developing climate change adaptation strategies should be part of all planning exercises, both at the level of individual units and collaboratively with other management units. This might encourage more units in the same broad geographical area to look for opportunities to coordinate on the development of regional management plans (see Table 9). A natural next step then would be to prioritize actions within the management plan. Different approaches may be used at different scales to decide on management activities across the public lands network or at specific sites. Such planning has already occurred in the National Forest System, where the Olympic, Mt. Baker, and Gifford Pinchot National Forests have combined resources to produce coordinated plans (Joyce and others 2008). The Olympic National Forest's exemplary strategic planning process also enables climate change considerations to be incorporated via its specific guidance on prioritization.

In some cases, existing management plans may already set the stage for climate adaptation. A good example is the Forest Service's adoption of an early detection/rapid response strategy for invasive species (Joyce and others 2008). This same thinking could be translated to an early detection/rapid response management approach to climate impacts. Even destructive extreme climate events can become management opportunities for addressing longstanding problems such as overbuilding in floodplains or degradation of coastal wetlands; in some estuaries it may be possible for decision makers to use up-front planning to prevent rebuilding in hazardous areas of high flood risk and to restore wetlands with provisions for their upland migration with sea level rise (Peterson and others 2008).

Table 8 Examples of legislation and regulation as barriers to and opportunities for adaptation

\begin{tabular}{|c|c|c|}
\hline \multicolumn{3}{|l|}{ Legislation and regulation } \\
\hline Perceived barrier & Opportunity & Examples \\
\hline $\begin{array}{l}\text { Legislation and agency policies may be } \\
\text { highly static, inhibit dynamic planning, } \\
\text { impede flexible adaptive responses and } \\
\text { force a fine-filter approach to management }\end{array}$ & $\begin{array}{l}\text { Re-evaluate capabilities of, or authorities } \\
\text { under, existing legislation to determine how } \\
\text { climate change can be addressed within the } \\
\text { legislative boundaries }\end{array}$ & $\begin{array}{l}\text { - Use state wildlife action plans to manage } \\
\text { lands adjacent to national wildlife refuges to } \\
\text { enable climate-induced species emigration } \\
\text { (Scott and others 2008) } \\
\text { - Incorporate climate change impacts into } \\
\text { priority setting for designation of new wild } \\
\text { and scenic rivers (Palmer and others 2008) }\end{array}$ \\
\hline
\end{tabular}


Table 9 Examples of management policies and procedures as barriers to and opportunities for adaptation

\begin{tabular}{|c|c|c|}
\hline \multicolumn{3}{|l|}{ Management policies and procedures } \\
\hline Perceived barrier & Opportunity & Examples \\
\hline $\begin{array}{l}\text { Seasonal management activities may be } \\
\text { affected by changes in timing and duration of } \\
\text { seasons }\end{array}$ & $\begin{array}{l}\text { Review timing of management activities and } \\
\text { take advantage of seasonal changes that } \\
\text { provide more opportunities for adaptation }\end{array}$ & $\begin{array}{l}\text { - Take advantage of shorter winter seasons } \\
\text { (longer prescribed fire season) to do fuel } \\
\text { treatments on more national forest acres } \\
\text { (Julius and others 2008) }\end{array}$ \\
\hline $\begin{array}{l}\text { Agency policies do not recognize climatic } \\
\text { change as a significant problem or stressor }\end{array}$ & $\begin{array}{l}\text { Take advantage of flexibility in planning } \\
\text { guidelines and processes to incorporate } \\
\text { adaptation to climate change }\end{array}$ & $\begin{array}{l}\text { - Where guidelines are flexible for meeting } \\
\text { strategic planning goals (e.g., maintain } \\
\text { biodiversity), re-prioritize management } \\
\text { actions to address effect of climate change on } \\
\text { achievement of goals (Julius and others } \\
\text { 2008) }\end{array}$ \\
\hline $\begin{array}{l}\text { Political boundaries do not necessarily align } \\
\text { with ecological processes; some resources } \\
\text { cross boundaries; checkerboard ownership } \\
\text { pattern with lands alternating between public } \\
\text { and private ownership at odds with } \\
\text { landscape-scale management } \\
\text { (see Joyce and others 2008) }\end{array}$ & $\begin{array}{l}\text { Identify management authorities with similar } \\
\text { goals and adjacent lands; share information, } \\
\text { create coalitions and partnerships that extend } \\
\text { beyond political boundaries to coordinate } \\
\text { management; acquire property for system } \\
\text { expansion }\end{array}$ & $\begin{array}{l}\text { - Implement active management at broader } \\
\text { landscape scales through existing multi- } \\
\text { agency management processes such as (1) } \\
\text { the Herger-Feinstein Quincy Library Group } \\
\text { Pilot and the FPA Adaptive Management } \\
\text { project on Tahoe National Forest (Julius and } \\
\text { others 2008), (2) the Greater Yellowstone } \\
\text { Coordinating Committee, and the Southern } \\
\text { Appalachian Man and the Biosphere } \\
\text { Program with relationships across } \\
\text { jurisdictional boundaries (Baron and others } \\
\text { 2008), (3) The Delaware River, managed } \\
\text { cooperatively as a partnership river (Julius } \\
\text { and others 2008) } \\
\text { - Coordinate dam management at the } \\
\text { landscape level for species that cross political } \\
\text { boundaries using dam operations } \\
\text { prospectively as thermal controls under } \\
\text { future climate changes (Palmer and others } \\
\text { 2008) }\end{array}$ \\
\hline
\end{tabular}

Management plans that are allowed to incorporate climate change adaptation strategies but that have not yet done so provide a blank canvas of opportunity. State wildlife action plans (Scott and others 2008) and ecosystem-based fishery management plans (Peterson and others 2008) are examples of this type of leveraging opportunity. Stakeholder processes can be an opportunity to move forward with new management approaches if public education campaigns on adaptation to climate change precede the stakeholder involvement. The issue of climate change has received sufficient attention that many people in the public have begun to demand actions by the agencies to address it.

\section{Human and Financial Capital}

Level of funding and staff capacity may pose significant barriers to adaptation to climate change (see Table 10). Managers may lack sufficient resources to deal with routine needs and even fewer resources to address unexpected events that will likely increase as a result of climate change. Further, while climate change stands to increase the scope of management by increasing both the area of land requiring active management and the planning burden per unit area (because of adaptive management techniques), some agencies also face decreasing personnel in some regions (Scott and others 2008). In addition, many agency personnel do not have adequate training, expertise, or understanding to effectively address emerging issues. Yet despite these constraints, there may be creative ways to augment the workforce and stretch budgets to alter or supplement practices that would enable adaptation to climate change.

Tackling the challenge of managing natural resources in the face of climate change requires that staff members not only feel valued but also empowered by their institutions. Many federal land management employees began their careers as passionate stewards of the nation's natural resources. With the threat of climate change further compounding management challenges, it is important that this passion be fully cultivated. Existing employees could be effectively trained (or specialist positions designated) to attack climate change issues within the context of their current job descriptions and management frameworks (Joyce and others 2008). For example, the National Park Service has recently implemented a program to educate 
Table 10 Examples of human and financial capital as barriers to and opportunities for adaptation

Human and financial capital

\begin{tabular}{|c|c|}
\hline Perceived barrier & Opportunity \\
\hline $\begin{array}{l}\text { Lack of incentive to take risks, develop } \\
\text { creative projects; reward system focuses on } \\
\text { achieving narrowly prescribed targets; funds } \\
\text { allocated encourage routine, easily } \\
\text { accomplished activities }\end{array}$ & $\begin{array}{l}\text { Shift from a culture of punishing failure to one } \\
\text { that values creative thinking and supports } \\
\text { incremental learning and gradual } \\
\text { achievement of management goals }\end{array}$ \\
\hline
\end{tabular}

Examples

Little to no climate expertise within management units at regional and local levels; disconnect between science and management that impedes access to information
Use newly created positions or staff openings as opportunities to add climate change expertise; train resource managers and other personnel in climate change science
National and regional budget policies constrain Look for creative ways to augment the the altering or supplementing of current management practices to enable adaptation to climate change; general decline in staff resources and capacity workforce and stretch budgets to institute adaptation practices (e.g., individuals or parties with mutual interests in learning about or addressing climate change that may be engaged at no additional cost)
- Build into performance expectations of a gradient between success and failure (Baron and others 2008)

- Set up a systematic method for (1) learning from mistakes and successes, and (2) eliciting the experience and empirical data of front line managers, resource management personnel, and scientific staff (Baron and others 2008)

- Develop expertise through incorporation into existing Forest Service training programs like the silvicultural certification program, regional integrated resource training workshops, and regional training sessions for resource staffs (Joyce and others 2008)

- Develop managers' guides, climate primers, management toolkits, a Web clearinghouse, and video presentations (Joyce and others 2008)

- Augment budget and workforce through volunteers from the public or other sources such as institutions with compatible educational requirements, neighborhood groups, environmental associations, etc., such as the Reef Check Program that help collect coral reef monitoring data (Keller and others 2008)

- Identify organizations or citizens that benefit from adaptation to share implementation costs in order to avoid more costly impacts/ damages (Julius and others 2008) park staff on climate change issues, in addition to offering training for presenting this information to park visitors in 11 national parks (Baron and others 2008). Such activities offer a cost-effective mechanism for empowering existing employees with both knowledge and public outreach skills.

Agency employees play important roles as crafters and ultimate implementers of management plans and strategies. Risk aversion coupled with the uncertainty surrounding climate change could lead managers to opt for the noaction approach, when the impending severe effects of climate change should elicit the opposite response (e.g., Hall and Fagre 2003). Human resource policies that are supportive of employees who take risks and acknowledge that risks sometimes lead to mistakes will be critical for managers making difficult choices under climate change (see Table 10). A "safe-to-fail" policy-in which the system can recover without irreversible damage to either natural or human resources (e.g., careers and livelihoods) - would be exemplary of this approach (Baron and others 2008).

\section{Information and Science}

Effective collaboration and linkages among managers and resource scientists offer a variety of opportunities (see Table 11). First, resource scientists have monitoring data and research results that are often underused. Second, monitoring efforts could be conducted with specific objectives in mind to increase usefulness for managers. Finally, scientists can support management by targeting their research. All of these are opportunities for interactions among scientists and managers that provide information relevant to major management challenges. The need for monitoring efforts may provide impetus for a more unified approach across agencies or management regions, which would serve to not only provide more comprehensive information but also to minimize costs associated with monitoring efforts.

While it is laudable to seek more and better information, it is equally important for the resource management community to proceed with designing strategies that are robust 
Table 11 Examples of information and science as barriers to and opportunities for adaptation

Information and science

\begin{tabular}{ll}
\hline Perceived barrier & Opportunity \\
\hline $\begin{array}{l}\text { Often no inventory or baseline information } \\
\text { exists, and nothing is in place to detect } \\
\text { climate change impacts }\end{array}$ & $\begin{array}{l}\text { Identify existing monitoring programs for } \\
\text { management; develop a suite of climate } \\
\text { change indicators and incorporate them } \\
\text { into existing programs }\end{array}$
\end{tabular}

Historic conditions may no longer sufficiently inform future planning (e.g., "100-year" flood events may occur more often)

Lack of decision support tools, uncertainty in climate change science, and gaps in scientific data limits assessments of risks and efficacies

Occurrence of extreme climate events outside historical experience
Evaluate policies that use historic conditions and determine how to better reflect accurate baselines in the face of climate change; modify design assumptions to account for changing climate conditions

Identify and use all available tools/mechanisms currently in place to deal with existing problems to apply to climate-change related impacts

Use disturbed landscapes as templates for "management experiments" that provide data to improve adaptive management
Stakeholders have insufficient information to properly evaluate adaptation actions, and thus may oppose/prevent implementation of adaptation (e.g., salvaging harvests after disturbance). Appeals and litigation from external public results in no action
Inform public and promote consensus-building on tough decisions; invite input from a broad range of sources to generate buy-in across stakeholder interests

\section{Examples}

- Use programs such as the National Park Service vital signs for the Inventory and Monitoring Program, Global Fiducial Program, Long Term Ecological Research networks, and National Ecological Observatory Network to monitor climate change impacts and effectiveness of adaptation options (Baron and others 2008)

- Change emphasis from maintenance of "minimum flows" to the more sophisticated and scientifically based "natural flow paradigm," as is happening in some places (Palmer and others 2008)

- Hedge bets and optimize practices in situations where system dynamics and responses are fairly certain (Baron and others 2008)

- Use adaptive management in situations with greater uncertainty (Baron and others 2008)

- After fire, reforest with genotypes that are better adjusted to the new or unfolding regional climate with nursery stock tolerant to low soil moisture and high temperature, or with a variety of genotypes (Joyce and others 2008)

- Conduct public outreach activities with information on climate impacts and adaptation options-including demonstration projects with concrete results-through workshops, scoping meetings, face-to-face dialog, and informal disposition processes to increase buy in for management actions (Julius and others 2008)

- Use state and local stakeholders to develop management plans to gain support and participation in implementation and oversight of planning activities, as do the National Estuaries (Peterson and others 2008), the Coastal Habitat Protection Plans for fisheries management (Peterson and others 2008), and some National Forests (Joyce and others 2008) in the face of limited information. Due to uncertainties in modeling and in the response of ecosystems to climate change and to management interventions, precise information on some questions may be impossible (or prohibitively expensive or time consuming) to acquire. If this is the case and if the information is needed for a specific adaptation action, then it may be that the action is not practical or is at a high risk for failure with implementation.

Another need on the information and science front is investment in resources and training for the promotion of flexible approaches to adaptation management. This would include developing general guidance on the likely impacts of concern and their implications for ecosystem services and management. It could also mean investing in "climate science translators" who could work in partnership with managers and planners to translate the projections of climate models, understand likely impacts, and help design adaptation responses. These individuals would also function as outreach staff who could explain to the public what climate change might mean to long-standing recreational opportunities or management goals.

Many federal lands and waters provide excellent opportunities for educating the public about climate change. National parks and wildlife refuges already put extensive resources into education and outreach for environmental, ecological, and cultural subjects (Baron and 
others 2008; Scott and others 2008), and these efforts could be augmented to inform the public about climate change. Traditional communication venues such as information kiosks and signs, documentaries, and brochures could demonstrate the effects of various climate-change scenarios on specific places or systems, making use of photos or video documenting coral bleaching and retreating glaciers, or presenting modeling results of projected changes in specific lands or waters (Kerr 2004, 2005).

\section{Advancing the Nation's Capability to Adapt}

Even if actions are taken today to limit future greenhouse gas emissions, shifts in management and policies still will be necessary since concentrations of heat trapping gases resident in the atmosphere are already large enough to require adaptation actions (Myers 1979). Ecosystem responses to increasing concentrations are likely to be unusually fast, large, and non-linear in character. Further, more areas are becoming vulnerable to climate change because of anthropogenic constraints that restrict biological adaptations (IPCC 2007).

Given these realities, managers of federal land and waters are likely to find situations in which currently available adaptation strategies will not enable a manager to meet specific goals, especially where those goals are related to keeping ecosystems unchanged or species where they are. These circumstances will require fundamental shifts in how ecosystems are managed (Dietz and others 2003; Walker and others 2004; Hobbs and others 2006; Kokko and López-Sepulcre 2006). Such shifts may entail reformulating goals, managing cooperatively across landscapes, and looking forward to potential future ecosystem states and facilitating movement toward preferred states. These sorts of fundamental changes in management at local-to-regional scales may only be possible with coincident organizational changes at different levels of governance to empower managers to make major adjustments toward adaptation. Thus, successful management adaptation may require fundamental shifts in policies at regional, national, and potentially international scales (Lemos and Agrawal 2006; Young and others 2007; Rayfuse 2008).

The types of changes that may be needed at the national level can be divided into several categories: (1) management at appropriate scales, and not necessarily the scales of convenience or tradition; (2) increased collaboration among agencies; (3) rational approaches for establishing priorities and applying triage; and (4) management with expectation of ecosystem change. Although many agencies have embraced subsets of these needed changes, there is no example of the full suite being implemented as a best practices approach.
Manage at Appropriate Scales

Experiences gained from natural resource management programs and other activities offer insights into the application of ecosystem based management under changing climatic conditions. Ecosystem based management takes into account interactions among ecosystem components and management sectors to optimize the benefits of activities aimed at maintaining ecosystem services under a multitude of existing stressors (Peterson and Estes 2001; Peterson and others 2008; Levin and others 2009). One lesson learned from this approach is that it may be necessary to expand the management scale beyond the boundaries of a single habitat type, conservation area, or political or administrative unit to encompass an entire ecosystem or region. Currently, management plans for forests, national parks, wildlife refuges, rivers, estuaries, and marine protected areas are often developed for discrete geographies with specific attributes (species, ecosystems, commodities), without recognition that they may be nested within other systems (Kareiva and others 2008). For example, marine protected areas are often within national estuaries, and wild and scenic rivers are often within national parks. Plans are seldom developed to fully consider the matrix in which they are embedded and the extent to which those attributes may vary over time in response to drivers external to the management system. Climate change adaptation opportunities may be missed if land and water resources are thought of as distinct, static, or out of context of a regional and even continental arena. A better approach would be to systematically broaden and integrate management plans as much as possible. Although a single national park or national forest may have limited capacity for adaptation, the entire system of parks and forests and refuges in a region may have powerful capacities. When spatial scales of consideration are larger, federal agencies often have mutually reinforcing goals that may result in the enhancement of their ability to manage cooperatively across landscapes (Leeworthy and Wiley 2003).

\section{Expand Interagency Collaboration, Integration,} and Lesson-Sharing

The scale of the challenge posed by climate disruption and the uncertainty surrounding future changes demand coordinated, collaborative responses that go far beyond traditional "agency-by-agency" responses to stressors and threats. A recurring theme across CCSP (2008) is the need for a structured, interagency effort and for collaboration in everything from research to management and land acquisition. Scientists and managers across agencies and management systems would benefit from greater sharing of data, models, and experiences. It may be necessary to 
develop formal structures and policies that foster extensive interagency cooperation.

One interagency program established specifically to address climate change research is the U.S. Climate Change Science Program (CCSP). The goals of this program are to develop scientific knowledge of the climate system, causes of changes in the system, and the effects of such changes on ecosystems, society, and the economyall in order to determine how best to apply that knowledge to decision-making. Climate change research conducted across 13 U.S. government departments and agencies is coordinated through the CCSP. The CCSP could be expanded to include management research and coordination to bridge the gap between resource management needs and scientific research priorities. This would enhance the goal of the CCSP to apply existing knowledge to decisionmaking.

While the CCSP may be the most relevant example of interagency collaboration for climate change, other programs such as the National Invasive Species Council, the Joint Fire Science Program, and National Interagency Fire Center could also serve as models. The analogy for climate change adaptation would be a group that would coordinate management activities, interpret research findings, inform on priority-setting, and disseminate data and tools. One option would be to designate climate experts to advise agency scientists at both national and site levels with guidance, translation of climate impact projections, and coordination across agencies (Kareiva and others 2008). Regardless of the exact collaborative structure, any interagency effort would benefit from the coordination of regional and national monitoring databases that can access and readily provide comprehensive information. This would increase the capacity to make informed decisions related to climate-induced changes, and the pooling of resources would allow for more effective data generation and sharing. Ideally, this would be a web-based clearinghouse with maps, a literature database, and pertinent models that could be easily downloaded and updated frequently as new information becomes available.

\section{Re-Evaluate Priorities and Consider Triage}

Climate change not only requires consideration of how to adapt management approaches; it also requires reconsideration of management objectives. In a world with unlimited resources and staff time, climate adaptation would simply be a matter of management innovation, monitoring, and more scientific research. In reality, priorities may need to be re-examined and re-established to focus adaptation efforts appropriately and make the best use of limited resources (CCSP 2008; Kareiva and others 2008). At the regional scale, one example of the type of change that may be needed is in selected estuaries where freshwater flow patterns are expected to change and salt water is expected to penetrate further upstream. Given this scenario, combined with the goal of protecting anadromous fishes, models could be used to project shifts in critical propagation habitats, and management efforts could be refocused to those sites (Peterson and others 2008).

In the example above, the goal is still attainable with some modifications. However, in general, resource managers could face significant constraints on their authority to re-prioritize and make decisions about which goals to modify and how to accomplish those modifications (Joyce and others 2008). National-level policies and priorities may have to be re-examined with thought toward how to accommodate and enable such changes in management at the regional level.

Because climate-driven changes in some ecological systems are likely to be extreme, priority-setting eventually may have to involve triage (Metzger and others 2005; Millar and others 2007). Some goals may have to be abandoned and new goals established if climate change effects are severe enough. Even with substantial management efforts, some systems may not be able to maintain the ecological properties and services that they provide in today's climate. For other systems or species, the cost of adaptation may far outweigh the ecological, social, or economic returns it would provide. In such cases, resources may be better invested elsewhere. One simple example of triage would be the decision to abandon habitat management efforts for a population of an endangered species on land at the "trailing" edge of its shifting range (Scott and others 2008). If the refuge that currently provides habitat for the species will be unsuitable within the next 50 years, it might be best to actively manage for habitat elsewhere and, depending on the species and the circumstances, investigate the potential for relocation. Such decisions will have to be made with extreme care (Scott and others 2008). In addition to evaluating projected trends in climate and habitat suitability, it will be necessary to monitor the species or habitats in question to determine whether the projected trends are being realized. All of the changes in management discussed in the next section would likely require fundamental changes in policy and engagement in triage at the national level.

\section{Manage for Change}

Agencies have established best practices based on many years of past experience. Unfortunately, dramatic climate change will change the rules of the game, rendering some of yesterday's best practices tomorrow's bad practices. Experienced managers now realize that they can anticipate changes in conditions, especially conditions that might 
alter the impacts of grazing, fire, logging, harvesting, recreation, sand so forth. Such anticipatory thinking will be critical, as climate change will likely exceed ecosystem thresholds over time such that strategies to increase ecosystem resilience will no longer be effective (Millar and others 2007). At this point, major shifts in ecosystem processes, structures, and components will be unavoidable, triggering a need to "manage for change".

Managing for change means actively managing an ecosystem through a transformation to a new state (see Walker and others 2004). This could involve, for example, using species properly suited to the expected future climate when revegetation and silviculture are used for post-disturbance rehabilitation; genotypes and species (including "new" species) that are better adjusted to projected changes in mean temperature, rainfall, variability and extremes could be used. In Tahoe National Forest, managing for change may mean that white fir would be favored over red fir, pines would be preferentially harvested at high elevations over fir, and species would be shifted upslope within expanded seed transfer guides (Joyce and others 2008). As another example, given climate change, some restoration may cease to be an appropriate undertaking. In a situation where warming waters render selected river reaches no longer suitable for salmon, restoration of those reaches may not be a realistic management activity (Joyce and others 2008). The same applies to meadows, where restoration efforts may need to be abandoned due to probable succession to non-meadow conditions. Additional examples of adaptation options for managing for change, drawn from across the management systems reviewed in CCSP (2008), are presented in Table 12 .

The task of managing for change may be difficult because trajectories of ecosystem alterations under climate change may be highly uncertain. This renders management goals less clear. Under these circumstances, scenario-based planning provides a key to moving forward. Development of realistic scenario-based plans may require a philosophical shift concerning when species or systems can be preserved, when restoration is an appropriate post-disturbance response, etc. For example, as illustrated poignantly in estuaries, it is impractical to attempt to keep ecosystem boundaries static. After a flood, there is often intense pressure to restore to the pre-flooding state (Peterson and others 2008). To ensure sound management responses, guidelines for the scenarios under which restoration and rebuilding should occur (or be abandoned) could be established in advance of disturbances. In this sense, disturbances could become opportunities for managing toward a distribution of human population and infrastructure that is more realistic given a changing climate.

Managing for change may also be difficult from a societal perspective as well as an ecological perspective. The public appreciates iconic ecosystems and expects that their protected status means that they will be maintained in their current state. A common perception has been that the mandate of management agencies is to maintain public lands and waters unchanged, and the public may not recognize the potential impossibility of this goal. Since management will not be able to prevent change, it will be important to manage the public's expectations as part of "managing for change".

\section{Conclusions}

To date, most of the literature on adaptation to climate change has focused on strategies for "managing for resilience"; indeed, resilience approaches represent the bulk of what managers have in their adaptation toolkit today. This

Table 12 Adaptation options for managing in the context of major climatic and ecological changes (modified from Kareiva and others 2008)

Adaptation options for managing for change

$\checkmark$ Assist transitions, population adjustments, and range shifts through manipulation of species mixes, altered genotype selections, modified age structures, and relocations

$\checkmark$ Rather than focusing only on historic distributions, spread species over a range of environments according to modeled future conditions

$\checkmark$ Proactively manage early successional stages that follow widespread climate-related mortality by promoting diverse age classes, species mixes, genetic diversity, etc., at landscape scales

$\checkmark$ Identify areas that supported species in the past under similar conditions to those projected for the future and consider these sites for establishment of "neo-native" plantations or restoration sites

$\checkmark$ Favor the natural regeneration of species better adapted to projected future conditions

$\checkmark$ Realign management targets to recognize significantly disrupted conditions, rather than continuing to manage for restoration to a "reference" condition that is no longer realistic given climate change

$\checkmark$ Manage the public's expectations as to what ecological states will be possible (or impossible) given the discrepancy between historical climate conditions and current/future climate conditions

$\checkmark$ Develop guidelines for the scenarios under which restoration projects or rebuilding of human structures should occur after climate disturbances 
focus makes sense given that the current goals of natural resource management in the United States revolve around the preservation of species, biodiversity, ecosystems, and ecosystem services and the avoidance of major losses and ecosystem shifts. Given these existing mandates, understanding and testing resilience strategies, as well as finding ways to overcome barriers to their implementation, is an important endeavor because it may be possible to continue managing some systems for decades or more in the face of climate change by bolstering their resilience. The degree to which this will be possible (i.e., for how long, for which systems, and using which strategies for greatest effectiveness) remains to be seen and is an important area for research and testing. Yet it is clear that adjustments will have to be made in current management practices in terms of timing, placement, scaling, and coordination in order to support ecosystem resilience in the context of a rapidly changing climate.

At the same time, it is also clear that some ecosystems will soon be—or in some cases already are—going through major transitions as climate change causes tolerance thresholds to be exceeded. This reality necessitates that managers begin an additional focus on "managing for change", which involves planning for the management of unavoidable ecosystem shifts and for the use of a triage approach to priority-setting. The aim should be to prioritize cases where management can influence the trajectory of ecosystem shifts toward new "stable states" that provide valued ecosystem services. This will be a challenging proposition since it is difficult to anticipate threshold changes and because the array of potential states into which a system may change is highly uncertain; thus concentrated research to understand the characteristics and indicators of threshold responses will be essential. Impact assessment, which is such an important tool for managing for resilience, may become even more important for investigating the nature of thresholds that trigger managing for change.

While there is an immediate need to address managing for change, this does not mean that managing for resilience will no longer be a useful concept. Resilience strategies can be used to forestall losses and slow the approach to thresholds, thereby buying time for managers to plan how best to manage upcoming transitions. Furthermore, after a given ecosystem shift has occurred, the goal for management of the new system state will again be resilience (in order to prevent losses of valued services due to direct anthropogenic impacts). Thus, successful resource management under climate change will require flexibility on the part of managers and decision makers in cycling between "managing for resilience" and "managing for change".

This conceptual flexibility must be accompanied by concomitant practical flexibility in social structures. Such flexibility will be essential for supporting and encouraging management at larger spatial scales, promoting and enabling partnerships across agencies and organizations, and making logical adjustments to policies, goals, and plans for meeting the challenges posed by climate change. Without a doubt, the degree of flexibility and creativity that will be needed to address the ever-increasing challenges of climate change is unprecedented. Only with a transformation of management and goal-setting, from the traditional static view to a highly dynamic and variable approach, will it be possible to make significant advances in adapting to climate change.

Acknowledgments We thank all of our fellow authors of the Climate Change Science Program publication, Preliminary Review of Adaptation Options for Climate-Sensitive Ecosystems and Resources (CCSP 2008), whose ideas and insights contributed greatly to this article. We thank especially the lead authors of the management system chapters: J. Baron, B. Griffith, L. Joyce, B. Keller, M. Palmer, C. Peterson, and M. Scott. We would also like to acknowledge the support of EPA's National Center for Environmental Assessment in the Office of Research and Development, and especially our colleagues in EPA's Global Change Assessment Staff for many helpful discussions and comments during the conceptual development of this article. Special thanks go to G. Blate and A. Babson for their contributions. Finally, we thank two anonymous reviewers for their many useful comments and suggestions.

Open Access This article is distributed under the terms of the Creative Commons Attribution Noncommercial License which permits any noncommercial use, distribution, and reproduction in any medium, provided the original author(s) and source are credited.

\section{References}

Adger WN, Agrawala S, Mirza MMQ, Conde C, O'Brien K, Pulhin J, Pulwarty R, Smit B, Takahashi K (2007) Assessment of adaptation practices, options, constraints and capacity. In: Parry ML, Canziani OF, Palutikof JP, van der Linden PJ, Hanson CE (eds) Climate change 2007: impacts, adaptation and vulnerability. Contribution of working group II to the fourth assessment report of the intergovernmental panel on climate change. Cambridge University Press, Cambridge, UK, pp 717-743. http://www. ipcc.ch/ipccreports/ar4-wg2.htm. Accessed April 2009

Arvai J, Bridge G, Dolsak N, Franzese R, Koontz T, Luginbuhl A, Robbins P, Richards K, Korfmacher KS, Sohngen B, Tansey J, Thompson A (2006) Adaptive management of the global climate problem: bridging the gap between climate research and climate policy. Climatic Change 78:217-225

Baron JS, Allen CD, Fleishman E, Gunderson L, McKenzie D, Meyerson L, Oropeza J, Stephenson N (2008) National parks. In: Julius SH, West JM (eds) Baron JS, Griffith B, Joyce LA, Kareiva P, Keller BD, Palmer MA, Peterson CH, Scott JM (authors) Preliminary review of adaptation options for climatesensitive ecosystems and resources. A Report by the U.S. climate change science program and the subcommittee on global change research. United States Environmental Protection Agency, Washington, DC, pp 4-1 to 4-68

Bennett EM, Cumming GS, Peterson GD (2005) A systems model approach to determining resilience surrogates for case studies. Ecosystems 8:945-957 
Burkett V, Wilcox D, Stottlemyer R, Barrow W, Fagre D, Baron J, Price J, Neilson JL, Allen CD, Peterson DL, Ruggerone G, Doyle $\mathrm{T}$ (2005) Nonlinear dynamics in ecosystem response to climatic change: case studies and policy implications. Ecological Complexity 2:357-394

Burton I, Malone E, Huq S, Lim B, Spanger-Siegfried E (2005) Adaptation policy frameworks for climate change: developing strategies, policies and measures. Cambridge University Press, Cambridge, UK, $253 \mathrm{pp}$

Carpenter SR, Ludwig D, Brock WA (1999) Management of eutrophication for lakes subject to potentially irreversible change. Ecological Applications 9:751-771

Carpenter SR, Bennett EM, Peterson GD (2006) Scenarios for ecosystem services: an overview. Ecology and Society 11(1):29

Carter TR, Parry ML, Harasawa H, Nishioka S (1994) IPCC technical guidelines for assessing climate change impacts and adaptations. University College, London and Centre for Global Environmental Research, Japan, $59 \mathrm{pp}$

Carter TR, Jones RN, Lu X (2007) New assessment methods and the characterisation of future conditions. In: IPCC (ed) Climate change 2007: climate change impacts, adaptation, and vulnerability, chap 2. Cambridge University Press, Cambridge, UK, pp 133-171

CCSP (2008) Preliminary review of adaptation options for climatesensitive ecosystems and resources. In: Julius SH, West JM (eds) Baron JS, Griffith B, Joyce LA, Kareiva P, Keller BD, Palmer MA, Peterson CH, Scott JM (authors) A report by the U.S. climate change science program and the subcommittee on global change research. US Environmental Protection Agency, Washington, DC, $873 \mathrm{pp}$

Cumming GS (2007) Global biodiversity scenarios and landscape ecology. Landscape Ecology 22(5):671-685

Dessai S, Hulme M, Lempert R (2009) Do we need better predictions to adapt to a changing climate? Eos 90(13):111-112

Dietz T, Ostrom E, Stern PC (2003) The struggle to govern the commons. Science 302(5652):1907-1912

Dixon GE (2003) Essential FVS: a user's guide to the forest vegetation simulator. US Department of Agriculture, Forest Service, Forest Management Service Center, Fort Collins, CO, $193 \mathrm{pp}$

FEMAT (Forest Ecosystem Management, Assessment Team) (1993) Forest ecosystem management: an ecological, economic, and social assessment. United States Government Printing Office, Washington, DC

Gregory R, Failing L (2002) Using decision analysis to encourage sound deliberation: water use planning in British Columbia, Canada. Journal of Policy Analysis and Management 21:492499

Gregory R, Ohlson D, Arvai J (2006) Deconstructing adaptive management: criteria for applications to environmental management. Ecological Applications 16(6):2411-2425

Grime JP, Brown VK, Thompson K, Masters GJ, Hillier SH, Clarke IP, Askew AP, Corker D, Kielty JP (2000) The response of two contrasting limestone grasslands to simulated climate change. Science 289(5480):762-765

Grimsditch GD, Salm RV (2006) Coral reef resistance and resilience to bleaching. IUCN resilience science group working paper series. No 1. IUCN The World Conservation Union, Gland, Switzerland and The Nature Conservancy, Narragansett, RI, 52 $\mathrm{pp}$

Groffman PM, Baron JS, Blett T, Gold AJ, Goodman I, Gunderson LH, Levinson BM, Palmer MA, Paerl HW, Peterson GD, Poff NL, Rejesk DW, Reynolds J, Turner MG, Weathers KC, Wiens J (2006) Ecological thresholds: the key to successful environmental management or an important concept with no practical application? Ecosystems 9:1-13
Groom MJ, Meffe GK, Carroll CR (eds) (2006) Principles of conservation biology. Sinauer Press, Sunderland, MA, 701 pp

Gunderson LH (2000) Ecological resilience-in theory and application. Annual Review of Ecology and Systematics 31:425-439

Hall MHP, Fagre DB (2003) Modeled climate-induced glacier change in Glacier National Park, 1850-2100. BioScience 53(2): $131-140$

Hannah L, Midgley GF, Millar D (2002) Climate change-integrated conservation strategies. Climate Change and Conservation Special Issue, Global Ecology \& Biogeography 11:485-495

Hansen LJ, Biringer JL, Hoffman JR (eds) (2003) Buying time: a user's manual for building resistance and resilience in natural systems. World Wildlife Fund, Washington, DC

Heller NE, Zavaleta ES (2009) Biodiversity management in the face of climate change: a review of 22 years of recommendations. Biological Conservation 142:14-32

Hobbs RJ, Arico S, Aronson J, Baron JS, Bridgewater P, Cramer VA, Epstein PR, Ewel JJ, Klink CA, Lugo AE, Norton D, Ojima D, Richardson DM, Sanderson EW, Valladares F, Vilà M, Zamora R, Zobel M (2006) Novel ecosystems: theoretical and management aspects of the new ecological world order. Global Ecology and Biogeography 15:1-7

Hoegh-Guldberg O, Hughes L, McIntyre S, Lindenmayer DB, Parmesan C, Possingham HP, Thomas CD (2008) Assisted colonization and rapid climate change. Science 321(5887):345346

Holling CS (1973) Resilience and stability of ecological systems. Annual Review of Ecology and Systematics 4:1-23

Holling CS (ed) (1978) Adaptive environmental assessment and management. Wiley, London, England, 377 pp

IPCC (1994) IPCC Technical guidelines for assessing climate change impacts and adaptations. In: Carter TR, Parry ML, Harasawa H, Nishioka S (eds) Prepared by working group II and WMO/ UNEP, CGER-IO15-'94. University College -London, UK and Center for Global Environmental Research, National Institute for Environmental Studies, Tsukuba, Japan, 59 pp

IPCC (2001) Climate change 2001: the scientific basis. In: Houghton JT, Ding Y, Griggs DJ, Noguer M, van der Linden PJ, Dai X, Maskell K, Johnson CA (eds) Contribution of working group I to the third assessment report of the intergovernmental panel on climate change. Cambridge University Press, Cambridge, United Kingdom and New York, NY, USA, 881 pp

IPCC (2007) Summary for policymakers, In: Solomon S, Qin D, Manning M, Chen Z, Marquis M, Avery KB, Tignor M, Miller HL (eds) Climate change 2007: the physical science basis. Contribution of working group I to the fourth assessment report of the intergovernmental panel on climate change. University of Cambridge Press, Cambridge, United Kingdom and New York, NY, $142 \mathrm{pp}$

IPCC-TGICA (2007) General guidelines on the use of scenario data for climate impact and adaptation assessment, version 2. In: Carter TR (lead author) Alfsen K, Barrow E, Bass B, Dai X, Desanker P, Gaffin SR, Giorgi F, Hulme M, Lal M, Mata LJ, Mearns LO, Mitchell JFB, Morita T, Moss R, Murdiyarso D, Pabon-Caicedo JD, Palutikof J, Parry ML, Rosenzweig C, Seguin B, Scholes RL, Whetton PH (contributing authors) Task group on data and scenario support for impact and climate assessment, intergovernmental panel on climate change. University of Cambridge Press, Cambridge, United Kingdom and New York, NY, 66 pp

Jackson JBC, Kirby MX, Berger WH, Bjorndal KA, Botsford LW, Bourque BJ, Bradbury RH, Cooke R, Erlandson J, Estes JA, Hughes TP, Kidwell S, Lange CB, Lenihan HS, Pandolfi JM, Peterson CH, Steneck RS, Tegner MJ, Warner RR (2001) Historical overfishing and the recent collapse of coastal ecosystems. Science 293(5530):629-638 
Johnson T, Weaver C (2009) A framework for assessing climate change impacts on water and watershed systems. Environmental Management 43:118-134

Joyce LA, Blate GM, Littell JS, McNulty SG, Millar CI, Moser SC, Neilson RP, O'Halloran KA, Peterson DL (2008) National forests. In: Julius SH, West JM (eds) Baron JS, Griffith B, Joyce LA, Kareiva P, Keller BD, Palmer MA, Peterson CH, Scott JM (authors) Preliminary review of adaptation options for climatesensitive ecosystems and resources. A report by the U.S. climate change science program and the subcommittee on global change research. United States Environmental Protection Agency, Washington, DC, pp 3-1 to 3-127

Julius SH, West JM, Airamé S, Barber RT, Baron JS, Blate GM, Causey B, Christian RR, Cottingham KL, Friedlander A, Griffith B, Johnson J, Joyce LA, Keller BD, Lettenmaier D, Littell JS, Lotze HK, McGuire AD, McNulty SG, Millar CI, Miller SL, O'Halloran KA, Oropeza J, Palmer MA, Peterson DL, Peterson CH, Piehler MF, Poff NL, Postel S, Richter B, Simenstad CA, Warner R, Wilson JW (2008) Annex A: case studies. In: Julius SH, West JM (eds) Baron JS, Griffith B, Joyce LA, Kareiva P, Keller BD, Palmer MA, Peterson CH, Scott JM (authors) Preliminary review of adaptation options for climate-sensitive ecosystems and resources. A report by the U.S. climate change science program and the subcommittee on global change research. United States Environmental Protection Agency, Washington, DC, pp A-1 to A-170

Kareiva P, Enquist C, Johnson A, Julius SH, Lawler J, Petersen B, Pitelka L, Shaw R, West JM (2008) Synthesis and Conclusions. In: Julius SH, West JM (eds) Baron JS, Griffith B, Joyce LA, Kareiva P, Keller BD, Palmer MA, Peterson CH, Scott JM (authors) Preliminary review of adaptation options for climatesensitive ecosystems and resources. A report by the U.S. climate change science program and the subcommittee on global change research. United States Environmental Protection Agency, Washington, DC, pp 9-1 to 9-66

Keller BD, Airamé S, Causey B, Friedlander A, Gleason DF, GroberDunsmore R, Johnson J, McLeod E, Miller SL, Steneck RS, Woodley C (2008) Marine Protected Areas. In: Julius SH, West JM (eds) Baron JS, Griffith B, Joyce LA, Kareiva P, Keller BD, Palmer MA, Peterson CH, Scott JM (authors) Preliminary review of adaptation options for climate-sensitive ecosystems and resources. A report by the U.S. climate change science program and the subcommittee on global change research. United States Environmental Protection Agency, Washington, DC, pp 8-1 to 8-95

Kerr RA (2004) Climate change: three degrees of consensus. Science 305:932-934

Kerr RA (2005) How hot will the greenhouse world be? Science 309(5731): 100

Kokko H, López-Sepulcre A (2006) From individual dispersal to species ranges: perspectives for a changing world. Science 313:789-791

Leeworthy VR, Wiley PC (2003) Profiles and economic contribution: general visitors to Monroe County, Florida 2000-2001. National Oceanic and Atmospheric Administration, Silver Spring, MD, 24 $\mathrm{pp}$

Lemos MC, Agrawal A (2006) Environmental governance. Annual Review of Environment and Resources 31:297-325

Levin PS, Fogarty MJ, Murawski SA, Fluharty D (2009) Integrated ecosystem assessments: developing the scientific basis for ecosystem-based management of the ocean. PLoS Biology 7(1):e1000014. doi:10.1371/journal.pbio.1000014

Lovejoy TE, Hannah L (2005) Climate change and biodiversity. Yale University Press, New Haven, CT, 401 pp

Mau-Crimmins T, Hubbard A, Angell D, Filippone C, Kline N (2005) Sonoran desert network: vitals signs monitoring plan. National Park Service. Intermountain Region, Denver, CO
Metzger MJ, Leemans R, Schröter D (2005) A multidisciplinary multi-scale framework for assessing vulnerability to global change. International Journal of Applied Earth Observation and Geoinformation 7:253-267

Millar CI, Stephenson NL, Stephens SL (2007) Climate change and forests of the future: managing in the face of uncertainty. Ecological Applications 17(8):2145-2151

Moir WH, Block WM (2001) Adaptive management on public lands in the United States: commitment or rhetoric? Environmental Management 28(2):141-148

Myers N (1979) The sinking arc. Pergamon Press, New York, NY

National Research Council (1999) Downstream: adaptive management of the Glen Canyon Dam and the Colorado River ecosystem. National Academies Press, Washington, DC

Palmer MA, Lettenmaier D, Poff NL, Postel S, Richter B, Warner R (2008) Wild and scenic rivers. In: Julius SH, West JM (eds) Baron JS, Griffith B, Joyce LA, Kareiva P, Keller BD, Palmer MA, Peterson $\mathrm{CH}$, Scott JM (authors) Preliminary review of adaptation options for climate-sensitive ecosystems and resources. A report by the U.S. climate change science program and the subcommittee on global change research. United States Environmental Protection Agency, Washington, DC, pp 6-1 to 6-73

Pauly D (1995) Anecdotes and the shifting baseline syndrome of fisheries. Trends in Ecology \& Evolution 10(10):430-431

Peterson CH, Estes JA (2001) Conservation and management of marine communities. In: Bertness MD, Gaines SD, Hay ME (eds) Marine community ecology. Sinauer Associates, Sunderland, MA, pp 469-507

Peterson GD, Cumming GS, Carpenter SR (2003) Scenario planning: a tool for conservation in an uncertain world. Conservation Biology 17(2):358-360

Peterson CH, Barber RT, Cottingham KL, Lotze HK, Simenstad CA, Christian RR, Piehler MF, Wilson J (2008) National estuaries. In: Julius SH, West JM (eds) Baron JS, Griffith B, Joyce LA, Kareiva P, Keller BD, Palmer MA, Peterson CH, Scott JM (authors) Preliminary review of adaptation options for climatesensitive ecosystems and resources. A report by the U.S. Climate change science program and the subcommittee on global change research. United States Environmental Protection Agency, Washington, DC, pp 7-1 to 7-108

Pianka ER (1970) On r- and k-selection. The American Naturalist 104(940):592-597

Porter ME (1985) Competitive advantage. Free Press, New York, NY

Rayfuse R (2008) Protecting marine biodiversity in polar areas beyond national jurisidiction. Review of European Community and International Environmental Law 17(1):3-13

Root TL, Schneider SH (2002) Climate change: overview and implications for wildlife. In: Schneider SH, Root TL (eds) Wildlife responses to climate change: North American case studies. Island Press, Washington, DC, pp 1-56

Scheffer MS, Carpenter SR (2003) Catastrophic regime shifts in ecosystems: linking theory to observation. Trends in Ecology \& Evolution 18:648-656

Scheffer M, Carpenter S, Foley JA, Folke C, Walker BH (2001) Catastrophic shifts in ecosystems. Nature 413:591-596

Schwartz P (1996) Art of the long view: planning for the future in an uncertain world. Currency Doubleday, New York, NY, pp 1-258

Scott JM, Griffith B, Adamcik RS, Ashe DM, Czech B, Fischman RL, Gonzalez P, Lawler JJ, McGuire AD, Pidgorna A (2008) National wildlife refuges. In: Julius SH, West JM (eds) Baron JS, Griffith B, Joyce LA, Kareiva P, Keller BD, Palmer MA, Peterson CH, Scott JM (authors) Preliminary review of adaptation options for climate-sensitive ecosystems and resources. A report by the U.S. climate change science program and the subcommittee on global change research. United States Environmental Protection Agency, Washington, DC, pp 5-1 to 5-100 
Stankey GH, Bormann BT, Ryan C, Shindler B, Sturtevant V, Clark RN, Philpot C (2003) Adaptive management and the Northwest Forest Plan-rhetoric and reality. Journal of Forestry 101(1):40 46

Tompkins EL, Adger NW (2004) Does adaptive management of natural resources enhance resilience to climate change? Ecol Soc 19(2):art 10

Turner BL II, Kasperson RE, Matson PA, McCarthy JJ, Corell RW, Christensen L, Eckley N, Kasperson JX, Luers A, Martello ML, Polsky C, Pulsipher A, Schiller A (2003) A framework for vulnerability analysis in sustainability science. Proceedings National Academy of Sciences 100:8074-8079

US-GAO (United States General Accounting Office) (2007) Climate change: agencies should develop guidance for addressing the effects on federal land and water resources. U.S. General Accounting Office, USA, GAO-07-863

Walker B, Salt D (2006) Resilience thinking: sustaining ecosystems and people in a changing world. Island Press, Washington, DC

Walker B, Holling CS, Carpenter SR, Kinzig A (2004) Resilience, adaptability and transformability in social-ecological systems.
Ecol Soc9(2):5. http://www.ecologyandsociety.org/vol9/iss2/art5/. Accessed April 2009

Walters CJ (1986) Adaptive management of renewable resources. MacMillan, New York, NY

Walters CJ, Hilborn R (1978) Ecological optimization and adaptive management. Annual Review of Ecology and Systematics 9:157-188

Willis KJ, Birks HJB (2006) What is natural? The need for a longterm perspective in biodiversity conservation. Science 314 (5803): 1261

Willows RI, Connell RK (eds) (2003) Climate adaptation: risk, uncertainty and decision-making. UKCIP Technical Report, UKCIP, Oxford, UK

Yohe GW, Tol RSJ (2002) Indicators for social and economic coping capacity-moving toward a working definition of adaptive capacity. Global Environmental Change 12:25-40

Young O, Osherenko G, Ekstrom J, Crowder LB, Ogden J, Wilson JA, Day JC, Douvere F, Ehler CN, McLeod KL, Halpern BS, Peach R (2007) Solving the crisis in ocean governance: place-based management of marine ecosystems. Environment 49(4):20-32 